\title{
LACLOD: LEARNING ANALYTICS FOR CHILDREN'S LOGIC DEVELOPMENT
}

\author{
Suzani Mohamad Samuri ${ }^{1,2}$, Dorroity Anak Emang ${ }^{1}$, Rahmadi Agus ${ }^{3}$, Bahbibi \\ Rahmatullah $^{1,2}$, Nurul Salini Mohamed Salleh ${ }^{1}$ and Mazlina Che Mustafa ${ }^{4}$ \\ ${ }^{1}$ Department of Computing, Faculty of Arts, Computing and Creative Industry, Sultan \\ Idris Education University, Perak, Malaysia \\ ${ }^{2}$ Data Intelligent and Knowledge Management (DILIGENT) Special Interest Group, \\ Sultan Idris Education University, Perak, Malaysia \\ ${ }^{3}$ Islamic University of Muhammad Arsyad Al Banjari Kalimantan, Indonesia \\ ${ }^{4}$ National Child Development Research Centre, Sultan Idris Education University, \\ Perak, Malaysia
}

\begin{abstract}
Learning Analytics for Children's Logic Development (LACLOD) is a web-based and mobile friendly learning analytic platform for assessing the logic development of children age 3 to 4 years old in TASKA PERMATA UPSI Malaysia. The platform is developed using Unity and connected through Google Analytics (GA) plugin where it tracked the user interaction for the application. LACLOD is designed only for mobile or tablet which is using Android. In this paper, the development of this learning analytic platform is presented. For evaluation of this system, observation and survey have been used, to get the feedback from 2 teachers (female) and 3 children (2 female and 1 male). Based on the evaluation, it can be seen that there are still rooms for improvement. Female children found it quit hard to understand the game but the male children looked satisfy because he knew on how to navigate the app and he actively played the app by himself. As for teachers, the acceptance to this kind of assessment is moderate, however they agree that this application can better improve the children's learning especially in logic development.
\end{abstract}

\section{KEYWORDS}

Learning analytics, Game-based learning, Unity software, Google analytics, and Assessment technology.

\section{INTRODUCTION}

Gaining student attention and an insight into the level of students' understanding during a lesson is an area that can be challenging for teachers. The assessment on the children progress will give teachers the insight they need as to how much the whole class and individual students have comprehended a topic. However, by the time the activity and assessment have been completed, the class will most likely have moved on to a new area of study. This means that students who have not quite grasped the concepts involved may be left behind. Use of technology such as digital games, for real time assessment has been the topic of interest for researchers in educational field. A report by Aladé et al., [1], shows that learning basic mathematical concepts in early childhood education can be made easier using interactive tablet-based games. Apart from that, integrating the element of Information and Communication Technology (ICT) in conventional teaching and learning allows for collaborative projects in primary education [2-4]. It can also increase the interest of students' learning in the introduction of colors, numbers and shapes [5]. In line with Education 4.0, it is foreseen that technology (game-based) can be the basis for learning analytics to explore the use of digital games in gaining insights of students' learning as well as exploring possibilities 
The International Journal of Multimedia \& Its Applications (IJMA) Vol.13, No. 1/2, April 2021

for real time assessment of students' performance [6-7]. According to de Freitas, et al., [8], there are numerous learning analytic applications, mostly provide learning through games to attract students' attention and give the results immediately where it will be saved into the databases or in the cloud. However, most literatures on this learning analytics are based on assessing the performance of students from secondary schools to higher education [8-13]. There are still few research on game-based learning analytics that involved early year's children.

Early years or early childhood is defined by UNESCO to be the period from birth to eight years old, whereby during this time children are highly influenced by the environment and people surrounded them. For early years education in Malaysia, this category are further refined. Children age four years and below received education that are designed under a standard national curriculum called Kurikulum PERMATA Negara [14], and all centres that are giving services to children under four years old are referred to as TASKA (Taman Asuhan Kanak-Kanak). While curriculum that looked into the development of children age five and six years old is called the Kurikulum Standard Pra Sekolah Kebangsaan (KSPK). While the development of children age seven and eight years old, is monitored based on another curriculum called the Kurikulum Standard Sekolah Rendah (KSSR). So, even though that UNESCO has defined children of early years to be from birth to eight years old, but the development of these children in Malaysia are monitored and assessed based on different curriculum as stated above [15].

In this paper, the development of a web-based learning analytic platform to assess the logic development of children age 3 and 4 years old in TASKA PERMATA UPSI, NCDRC, Malaysia is presented. This study is focusing only on logic development since activities related to logic is somehow can be quite challenging to some of the children at this age. Apart from that, activities related to logic is found to be easy to emulate in the form of digital games. The paper is organized as follows; Section I is an introduction and background. Section II provides the detail proposed methodology for development of the logic game and web platform. Section III discusses the experiment results. Finally, Section IV presents the concluding remarks.

\section{Method}

ADDIE model [16] is a systematic instructional design model consisting of five phases which are including analysis, design, development, implementation and evaluation. Each phase has an outcome that feeds into the next phase in the sequence.

\subsection{Analysis Phase}

In this phase, there are several things that need to take care of which includes the instructional goals, learner analysis, instructional analysis and objective analysis. Firstly, the instructional goals are the desired goals of what the children should be able to do in the system. The instructional goal is the children should be able to solve the activity in the system which in this case, related to children's logic development. Secondly, the learner analysis means to analyse who are the target audience, their prior knowledge and their experiences. The main focus in this phase is the target audience that is children of three and four years old. Their prior knowledge and experiences will be analyse by interviewing the class teachers. Objective analysis and instructional analysis and on the other hand are mainly defining clearly the objectives of the system which are to develop a system that can suggest a way on how to solve an activity in children's logic development, provide teachers a quick overview about the current learning process of the children and to evaluate the usability of the system. As for the instructional analysis, it is to determine on how to achieve the learning goals and how to present the content of learning in the system and what type of game used to present the learning activities. The learning content in this system has been constructed based 
The International Journal of Multimedia \& Its Applications (IJMA) Vol.13, No. 1/2, April 2021

on Bloom's Taxonomy level which includes remember, understand, apply, analyse, evaluate and create [17].

\subsection{Design Phase}

The learning strategies is the main focused in this phase, which the concern is on how to apply the learning content in the system. Once the learning strategies are gathered, a design for the system is created, which includes the user interface of the system, the number of links contained in a single page, the position of navigation bar, the position of the system icon and the position where the information is being displayed. Then, the prototype has been refined for several time, based on the feedback given by the teachers. Apart from that, other requirements are also identified in this phase, such as the use case, hardware and software requirements and functional requirements.

In this study, there will be eight (8) main use cases that have been designed, which includes children will have to choose for logic-based game and solve the logic-based game. Then, they can view their result after they solved the game. Besides, the children also can view the application's information or just quit. Since this application is integrated with Google Analytics (GA), the teachers are the only person who can login into the GA and they can view and save analytics report in it.

The functions designed in LACLOD will allow children to choose the game, solve it, view the results, and information on the applications and quit the game. As for the teachers, they can login to the Google Analytics (GA) via web browser using their laptop, desktop or tab where they enter by using their registered e-mail and password. Teachers also can view and save the analytics reports on the children's performance. Figures

As said, to insert images in Word, position the cursor at the insertion point and either use Insert | Picture | From File or copy the image to the Windows clipboard and then Edit | Paste Special | Picture (with "Float over text" unchecked).

The authors of the accepted manuscripts will be given a copyright form and the form should accompany your final submission.

\subsection{Development Phase}

As shown in the Table 1, there are 4 main softwares needed to develop this system. Wireframe Sketcher is used to sketch the user interface diagram, while UNITY is used to develop the game platform. The scripting used in this software is uncluttered and straightforward that brings fast iteration and execution of the programming environment. It is easy to use, debug and design simple co-routines which are the main reason for it to be used in this work. To support the Unity coding for editing, Microsoft Visual Studio 2017 is used. Lastly, to track all the users' performance and display all the analytics report, Google Analytics is utilized. Table 2 shows the hardware specifications needed for this system.

Table 1. The software needed to develop this system

\begin{tabular}{ll}
\hline Software & Description \\
\hline Wireframe Sketcher & User interface diagram \\
\hline UNITY & To develop LACLOD App \\
\hline Microsoft Visual Studio 2017 & To edit coding for Unity \\
\hline Google Analytics & To track application and create analytics report \\
\hline
\end{tabular}


The International Journal of Multimedia \& Its Applications (IJMA) Vol.13, No. 1/2, April 2021

Table 2. The hardware specifications to develop this system

\begin{tabular}{ll}
\hline Hardware & Specifications \\
\hline Processor & Intel ${ }^{\circledR}$ Core \\
\hline RAM & 4 GB $-7200 \mathrm{U}$ CPU @ 2.50 GHz 2.70 GHz \\
\hline Graphic card & NVIDIA GeForce 920MX \\
\hline Operating system & Windows 10 Home Sign Language \\
\hline
\end{tabular}

\subsection{Implementation and Evaluation Phase}

As In this phase, a procedure for guiding teachers and children is developed as the system will be delivered to the user. This is also the phase where the developer ensures that the system functions are in place, and all are fully functional. The evaluation phase is divided into two main parts, which is evaluation while developing the prototype and evaluation after the final prototype is developed. The first part involves two (2) teachers from TASKA PERMATA UPSI to refine requirements for the system to be developed. Teachers provide feedback to modify subsequent learning activities and experiences. The feedback gathered during this part measures reaction as well as identifies the functional of the system.

When the final prototype is developed, two (2) teachers and three (3) children (2 female and 1 male) were involved to evaluate the system. The children were selected by their teachers and all of them are four years old from TASKA PERMATA UPSI. This time, the objective of the evaluation is to determine the usability of the system. It also validates whether the learning went as planned, and it may also uncover any obstacles that may have emerged. Children are observed while they are using the system to assess for its usability. The observation checklist has been created based on Nielsen's usability framework [18] which look into the ease of learning by the children, ease of use and the effectiveness of the system. In order to have a basis to compare between the usability of the system, the following set of measures were adopted, which include the efficiency (time to accomplish tasks or throughput), learnability (time to learn and ease of learning) and satisfaction (comfort and acceptability of use).

The usability evaluation is conducted to some common functions in all the systems and conducted a rudimentary experiment where specific tasks are attempted on the systems and a quantitative index is given to each, per every measure above. At this stage, the children are required to test all the functions in the platform. First, they were observed while using this platform to evaluate its ease of use. After the children had learnt how to accomplish the task, then the teachers were asked to use the platform to see the children's performance. At this point, teachers gave their feedback on the ease of use and how well they understand the function of Google Analytics to help them understand their students' performance. Finally, children's experience, as well as their impression while engaging with the application have been included as the satisfaction factor. Apart from that, while executing this evaluation process, a black box testing with eight test cases shown in Table 3 were also conducted concurrently, to check for the full functioning of the application.

Table 3. The test cases for the functional testing of the application

\begin{tabular}{llll}
\hline LACLOD App & \multicolumn{2}{l}{ Google Analytics } \\
\hline TUC01 & Choose game & TUC07.1 & To view the total number of numbers of users in real time \\
\hline TUC04 & Quit game & TUC07.2 & To view which application's screen viewed the most \\
\hline TUC05 & View app info & TUC07.3 & To view the average time on one screen per one user \\
\hline & & TUC07.4 & To view the user's score \\
\hline & & TUC07.5 & To view which button the user interact the most \\
\hline
\end{tabular}


The International Journal of Multimedia \& Its Applications (IJMA) Vol.13, No. 1/2, April 2021

\section{FindingS}

\subsection{System Architecture}

Figure 1 shows the entire architecture of the platform developed to give an overview of the two main platform; the game platform and learning analytic platform. LACLOD system is designed to have two main users, which is children and teachers. In this platform, children will be allowed to choose for logic-based game and solve the game, they can also view their result and they can also view the application's information or just quit. As for the teachers, they can login into the Google Analytic and then view or save the analytics report of each children. The designed use case is as shown in Figure 2.

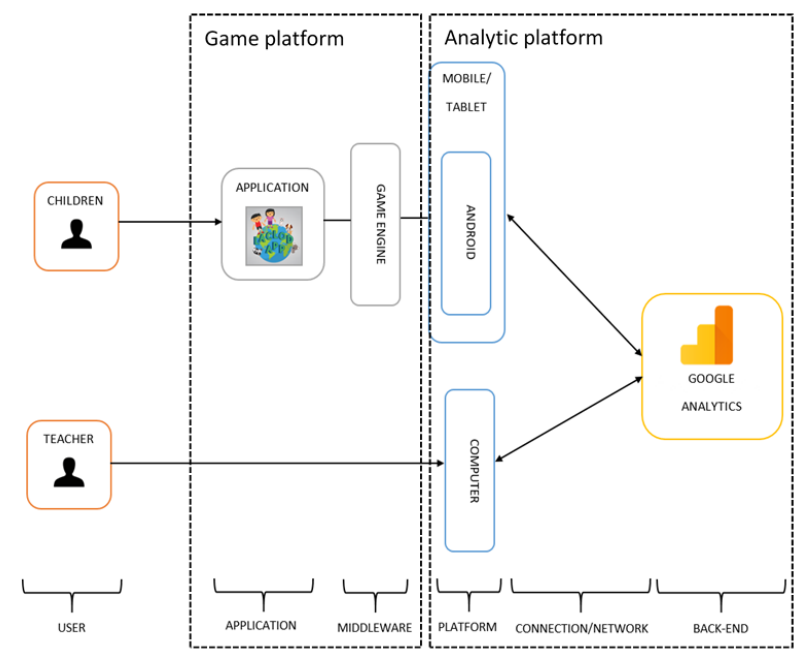

Figure 1. The system architecture of LACLOD system

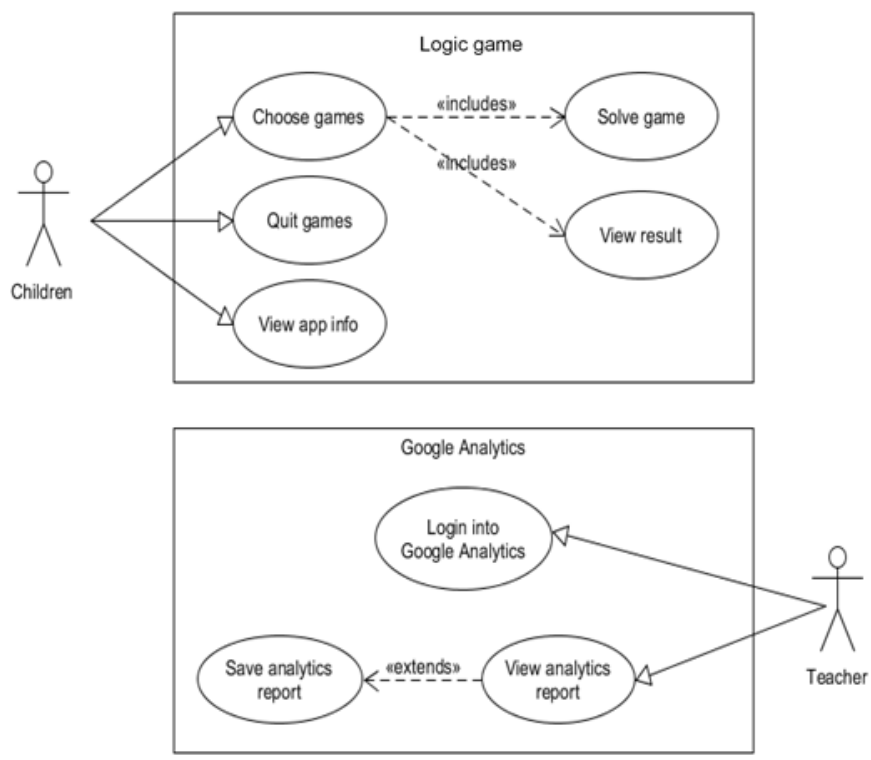

Figure 2. The designed use case for LACLOD system 
The International Journal of Multimedia \& Its Applications (IJMA) Vol.13, No. 1/2, April 2021

LACLOD will be used by children at TASKA PERMATA UPSI. This application is integrated with Google Analytics (GA), which user can use this application if they have mobile or tablet that running on Android operating system or computer with Windows for Google Analytics (GA). LACLOD allows children to choose the game to play. There are 3 games that the children can choose; Game 1: Count 1 until 10, Game 2: Match to the right number, and Game 3: Match to the same image. The function to play the game is compulsory after the children had chosen the game. For game 1, children have to click the correct answer. As for Game 2 and 3, children need to drag the object to the appropriate number or image. The function of LACLOD will provide the children to view the result after completing the game. The function of LACLOD will provide the children to quit the game if they does not want to play.

Meanwhile, for GA function, it is for the teachers to explore. The login function allows teachers to login into the GA via web browser through computer where they enter by using e-mail and password. Teachers also can track children's performance via reports provided in the GA embedded in LACLOD. Figure 3(a) until 3(e) show the example of developed interface for LACLOD.

\subsection{Evaluation Results}

\subsubsection{The test cases for the functional testing of the LACLOD application and Google Analytics}

The evaluation was done at TASKA PERMATA UPSI, NCDRC, involving 1 male and 2 female children of age three years old. The children were observed while using the application. The evaluation of this system is on the ease of use of the application by the children. Only three children were selected to test this application at TASKA PERMATA UPSI because Google Analytics can detect in real time only one user per one device. Since there are only three devices used, hence, the three children was selected.

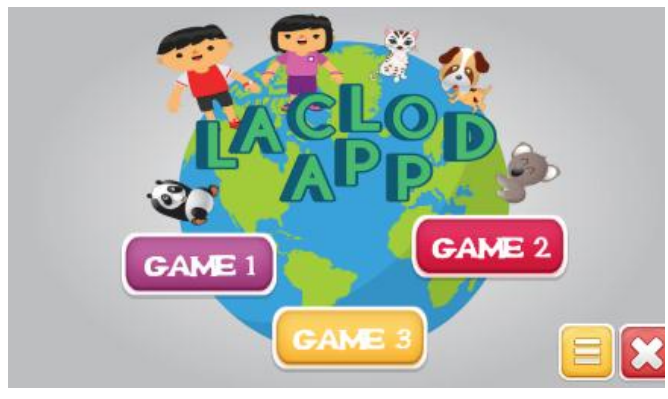

a. Main menu's interface

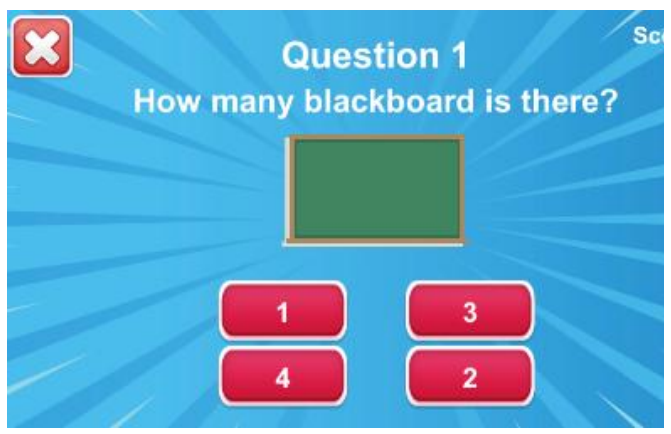

c. Interface for Game 1

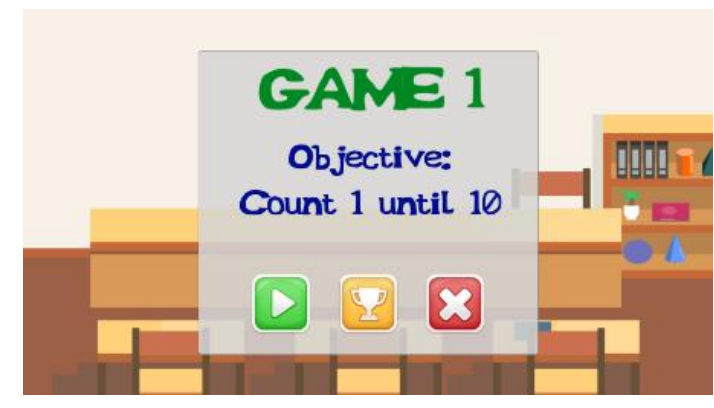

b. Menu for Game 1

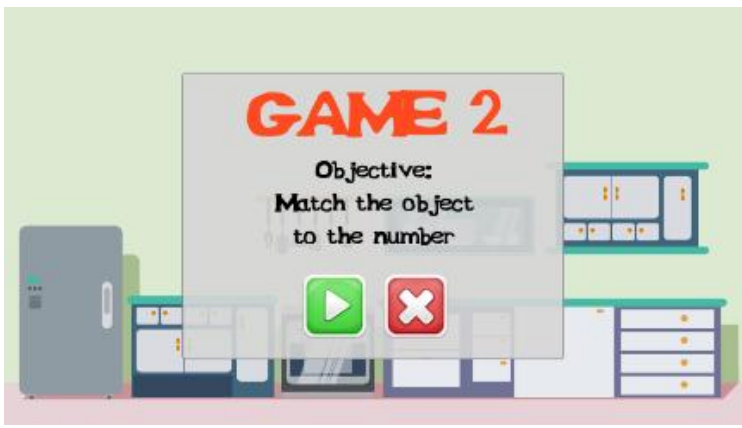

d. Menu for Game 2 
The International Journal of Multimedia \& Its Applications (IJMA) Vol.13, No. 1/2, April 2021

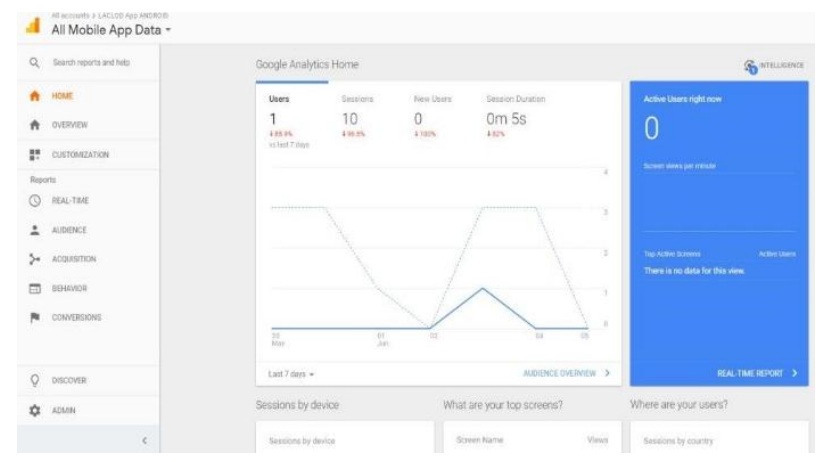

e. The Google Analytics home dashboard

Figure 3. LACLOD's interfaces

\subsubsection{The ease of use of LACLOD application for children}

To measure the ease of use of the application, observation is conducted while children are engaging with the application and by having a checklist. This checklist acts as a guidance for the observation experiments. The guidance is important to make sure the observation result satisfy the objective for this study. Figure 4 shows the results of this evaluation.

\subsubsection{The ease of use of LACLOD application and Google Analytics (GA) dashboard for teachers}

Apart from that, the evaluation also involved two teachers. They were asked regarding the ease of use of the application as well as the ease of use of Google Analytics (GA) as the teacher need to use the Google Analytics' dashboard to track their students' performance. This evaluation is done by asking directly to the teachers. Figure 5 and 6 show the feedback with regards to the ease of use of the application the ease of use of the GA respectively.

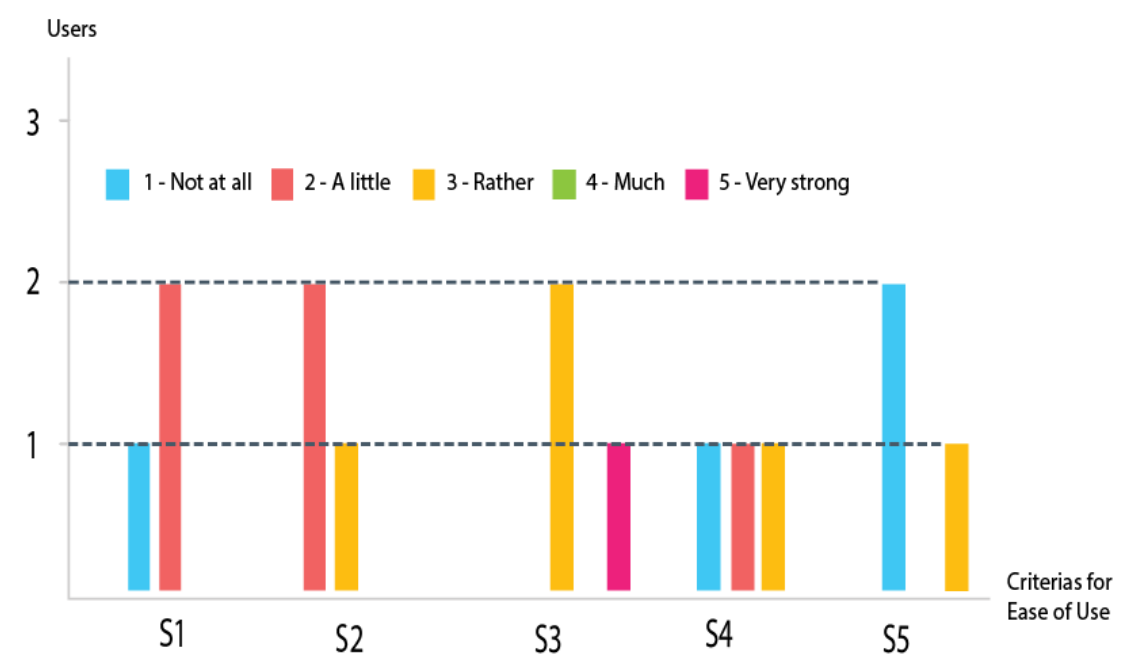

Figure 4. The ease of use of LACLOD application for children 
The International Journal of Multimedia \& Its Applications (IJMA) Vol.13, No. 1/2, April 2021

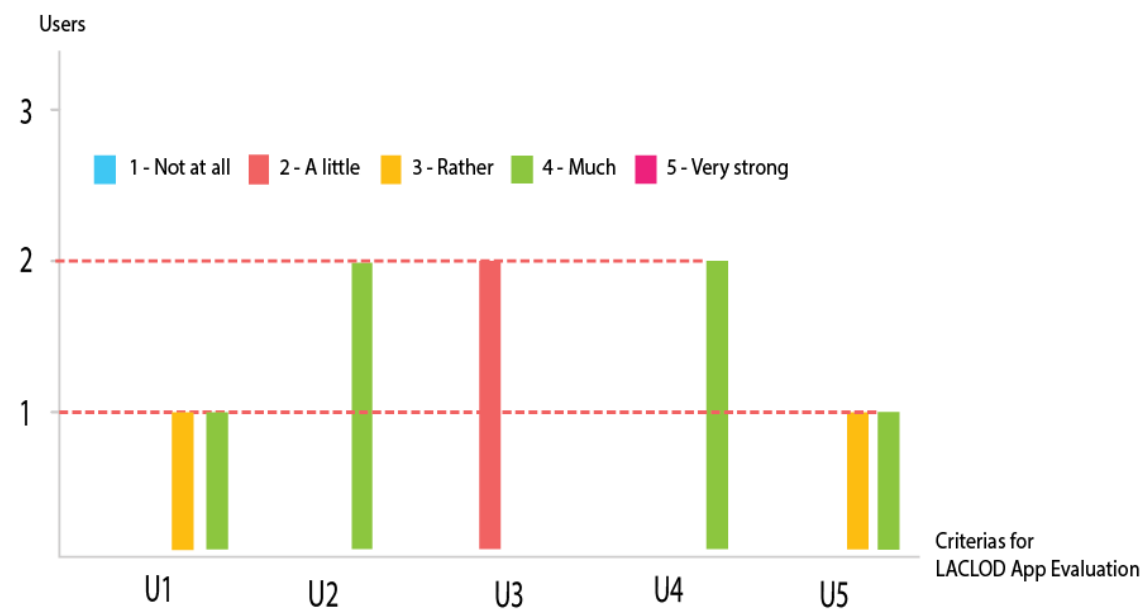

Figure 5. The ease of use of LACLOD application for the teachers

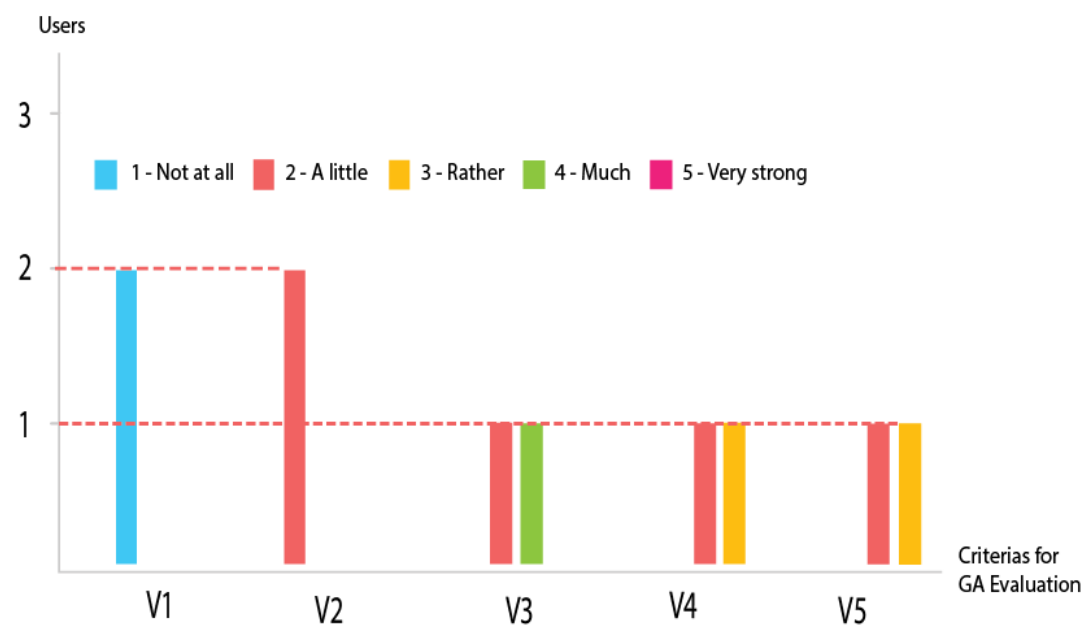

Figure 6. The ease of use of Google Analytics for the teachers

\section{DiscuSSION}

The results in Figure 4 shows that two children who were both female found a little hard while the male found it was not hard to navigate the application. Same goes to the second finding on the audio. Both female children found it little hard to hear the audio in the application but not the male children. The next observation on the use of buttons in the application, the results show that again, both female children have difficulties in using the buttons but as for the male, he has no problem as all. Another interesting finding is that, both female children do not know how to get started or play the game by themselves. They need assistance from their teachers but as for the male, he has no problem playing the game all by himself. An these observations bring us to the overall finding, that both female children are not happy while playing the game because they look struggling to find ways how to play and navigate through the games, but as for the male child, he looks satisfied and happy, as he know how to play the games and actively navigate through the application by himself. Even though the number of children involved in this study is not many, but based on the observation done, we could see that the male child is more attracted to the LACLOD application, 
The International Journal of Multimedia \& Its Applications (IJMA) Vol.13, No. 1/2, April 2021

as compared to the female. On this basis, future research can be done on the features that can be used to attract both male and female in the early years to play the educational game.

From bar chart shown in Figure 5, result from one of the teachers shows that it was quite hard to navigate the application while the other one said that it was much hard because the button are not labelled with text and it take much time to go to the next page in the application. Apart from that, both teachers agree that the audio is clear and understandable for adults but not for children, while the graphics used are suitable for children. For example, even though the game application has audio to read the text but it is not clear, which make users difficult to use the application. The background music should be made slower so that the audio can be heard more clearly. As for the Google Analytics (GA), both teachers are very new to it, as shown in Figure 6. They have no experience using GA and therefore they find it hard to understand how to use it. It took sometimes for them to familiarise with the GA interface and exploring the functions embedded in it. However, both of them agree that they can understand the usage of this GA in the application. Finally, both of them felt a little and rather to use the GA to track their students' performance because they have to open the GA via personal computer to view the analytics reports during the evaluation. Hence, from these observation and findings, we could suggest that, the usage of GA in games is beneficial for the teachers, provided that training is given to them beforehand. Teachers do appreciate the use of such technology in their daily teaching and learning activities, but the shift from conventional method to technology based, does take time and the application developed, must be made easier for children to use and teachers to track children's performance more efficiently.

\section{CONClusion}

In this study, an application called LACLOD has been developed with the objective to assess the logic development of children age 3 and 4 years old in TASKA PERMATA UPSI, NCDRC, Malaysia. This application is focusing only on logic development since activities related to logic is somehow can be quite challenging to some of the children at this range of age. The platform can be installed on mobile or tablet which are using Android platform. It is also integrated with Google Analytics (GA) plugin where it can track the children's performance in real time. The use of GA in this platform is foreseen as an added advantage since it allows teachers to track their students' performance at any time, as opposed to other game applications available in the market for early year's children. Besides that, this application is providing an audio to read each word for the text in the user interface. This is an advantage to children who are unable to read yet, they can hear the audio in order to use the application.

From the evaluation conducted, there are still rooms for improvement. Female children found it quit hard to understand the game but the male children looked satisfy because he knew on how to navigate the app and he actively played the app by himself. As for teachers, the acceptance to this kind of assessment is moderate, however they agree that this application can better improve the children's learning especially in logic development. For future work, this study can be further improved by including other developments of the children such as, creativity, language, etc. The focus group can also be widen to children of age five and above. Apart from that, this platform also can be improve in such a way that teachers will have an application to control the game played by the children as client and server. When the teachers can control the game, therefore it can avoid the children from skipping the games that they should play in the application. After the children are done solving the games, the analytics result can directly be viewed by the teacher without having them to login into GA via web. All in all, this learning analytic platform has the potential to be used in assessing early year children's logic development in future. 
The International Journal of Multimedia \& Its Applications (IJMA) Vol.13, No. 1/2, April 2021

\section{ACKNOWLEDGEMENT}

Special thanks to the National Child Development Research Centre (NCDRC), Data Intelligence and Knowledge Management (DILIGENT) SIG, Department of Computing, Faculty of Arts, Computing and Creative Industry, Sultan Idris Education University, for continuous support throughout this research.

\section{REFERENCES}

[1] Aladé, F., Lauricella, A. R., Beaudoin-Ryan, L., \& Wartella, E. (2016). Measuring with Murray: Touchscreen technology and preschoolers' STEM learning. Computers in Human Behavior, 62, 433441. doi.org/10.1016/j.chb.2016.03.080

[2] Iglesias Rodriguez, A., Garcia Riaza, B., \& Sanchez Gomez, M. C. (2016). Collaborative learning and mobile devices: An educational experience in Primary Education. Computers in Human Behavior. doi.org/10.1016/j.chb.2016.07.019

[3] Karkar, A., Ja'Am, J. M. Al, Foufou, S., \& Sleptchenko, A. (2016). An e-learning mobile system to generate illustrations for Arabic text. IEEE Global Engineering Education Conference, EDUCON, 1013-Apri(April), 184-191. doi.org/10.1109/EDUCON.2016.7474551.

[4] Rossetto, A. D. F., \& Dutra, A. (2016). The analysis of the use of mobile technology in 6-8 years old children's literacy process. 2016 International Symposium on Computers in Education, SIIE 2016: Learning Analytics Technologies, 9-12. doi.org/10.1109/SIIE.2016.7751830

[5] Dağal, A. B., Balat, G. U., Kanburoğlu, V., Şallı, D., \& Birbir, Y. (2015). The Development of English Computer Aided Education Program for Acquisition of Color, Number and Shape Concepts in Preschool Children without Foreign Language Education Background. Procedia - Social and Behavioral Sciences, 176, 87-94. doi.org/10.1016/j.sbspro.2015.01.447

[6] Guenaga, M., \& Garaizar, P. (2016). From Analysis to Improvement: Challenges and Opportunities for Learning Analytics. IEEE Revista Iberoamericana de Tecnologias del Aprendizaje, 11(3), 146-147.

[7] Siemens, G., \& d Baker, R. S. (2012). Learning analytics and educational data mining: towards communication and collaboration. In Proceedings of the 2nd international conference on learning analytics and knowledge (pp. 252-254). ACM.

[8] de Freitas, S., Gibson, D., Alvarez, V., Irving, L., Star, K., Charleer, S., \& Verbert, K. (2017). How to use gamified dashboards and learning analytics for providing immediate student feedback and performance tracking in higher education. In Proceedings of the 26th International Conference on World Wide Web Companion (pp. 429-434). International World Wide Web Conferences Steering Committee.

[9] Ali, M., Shatabda, S., \& Ahmed, M. (2017). Impact of learning analytics on product marketing with serious games in Bangladesh. In 2017 IEEE Region 10 Humanitarian Technology Conference (R10HTC) (pp. 576-579). IEEE.

[10] Tlili, A., Essalmi, F., Ayed, L. J. B., \& Jemni, M. (2017). A smart educational game to model personality using learning analytics. In 2017 IEEE 17 th International conference on advanced learning technologies (ICALT) (pp. 131-135). IEEE.

[11] Yi, B., Wang, Y., Zhang, D., Liu, H., Shu, J., Zhang, Z., \& Lv, Y. (2017). Learning Analytics-Based Evaluation Mode for Blended Learning and Its Applications. In 2017 International Symposium on Educational Technology (ISET) (pp. 147-149). IEEE.

[12] Spikol, D., Ruffaldi, E., Landolfi, L., \& Cukurova, M. (2017). Estimation of success in collaborative learning based on multimodal learning analytics features. In 2017 IEEE 17th International Conference on Advanced Learning Technologies (ICALT) (pp. 269-273). IEEE.

[13] Nor Zuhaidah Mohamed Zain, Maizatul Hayati Mohamad Yatim, Ummu Husna Azizan and Hasrina Baharum, (2020). Development of a Mobile Learning Application of Malay Vocabulary for Lower Secondary School Level. International Journal of Multimedia \& Its Application (IJMA), Vol. 12, No. 6, AIRCC.

[14] Kurikulum

PERMATA

Negara

(2013) http://www.programpermata.my/resources/download/KURIKULUM_PERMATA_NEGARA.pdf

[15] UNESCO (n.d.). Early Childhood Care and Education. https://en.unesco.org/themes/early-childhoodcare-and-education 
The International Journal of Multimedia \& Its Applications (IJMA) Vol.13, No. 1/2, April 2021

[16] Peterson, C. (2003). Bringing ADDIE to life: Instructional design at its best. Journal of Educational Multimedia and Hypermedia, 12(3), 227-241.

[17] Bloom, B. S. (1956). Taxonomy of educational objectives. Vol. 1: Cognitive domain. New York: McKay, 20-24.

[18] Nielsen, J. (1993). Usability Engineering. Boston: Academic Press.

\section{AUTHORS}

Suzani Mohamad Samuri is an Associate Professor in the Department of Computing, at Sultan Idris Education University, (UPSI) Malaysia. She is now the Head of Data Intelligent and Knowledge Management (DILIGENT) Special Interest Group in UPSI. Her current responsibility allows her to explore new research area related to big data, data visualization and learning analytic powered by various computational intelligence tools. Her research interests include data-driven modeling, intelligent-systems-based modeling and control, big data, data mining, data visualization and learning analytics.

Dorroity Anak Emang graduated from the Sultan Idris Educational University in 2019 with a bachelor's degree in Software Engineering (Education Software) with honours, where she learnt the programming language and solutions that she still implementing to this day. Currently she works as an associate application engineer for E2Open Malaysia Sdn Bhd. She is an accomplished engineer where she enjoys using her skills to contribute to the exciting technological advances that happen every day at E2Open.

Rahmadi Agus is a lecturer at the Islamic University of Kalimantan Muhammad Arsyad al-banjary, Banjarmasin. He gained his degree in the Informatics Engineering program, Faculty of Engineering, Kalimantan Islamic University, Banjarmasin in 2012. Graduated from the Master program in the Postgraduate program at Dian Nusawantoro University, Semaranga in 2014, and currently continuing his doctoral studies at Sultan Idris Education University, Malaysia. His research interest is in the fields of Learning Analytics and Game Education.

Bahbibi Rahmatullah is currently an Associate Professor in the Department of Computing, Faculty of Arts, Computing and Creative Industry, Sultan Idris Education University, Malaysia. She has authored a wide range of publications and had been invited to review articles for high impact journals and conferences. Current research interest includes Image and Signal Processing, Pattern Recognition, Machine Learning, Learning Analytics, Child Development, ICT and Education.

Nurul Salini is a PhD student at the Sultan Idris Education University. She's most passionate about project management especially in the area of Information Technology, and just recently successfully completed managing projects related to the development of a system for early childhood database. Her venture in early childhood field opens new opportunity in exploring learning analytics as one of the methods to measure children development throughout their early years.

Mazlina Che Mustafa is an Associate Professor at Department of Early Childhood Education, Faculty of Human Development, Sultan Idris Education University, Malaysia. She is also the Director of National Child Development Research Centre (NCDRC), Universiti Pendidikan Sultan Idris. She obtained her PhD in Education (Early Childhood) from University of Canterbury, New Zealand. Her research interests focus on quality in early childhood education and care, English for young learners, project approach in early childhood and teacher development.
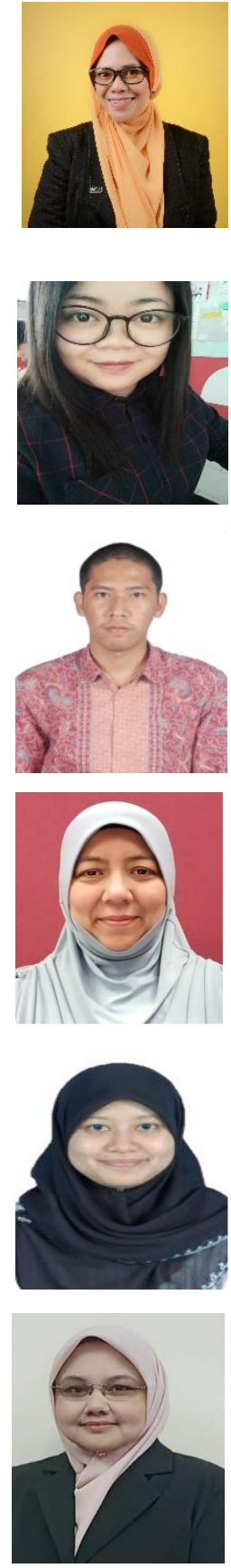
The International Journal of Multimedia \& Its Applications (IJMA) Vol.13, No. 1/2, April 2021

\section{APPENDIX}

Table 4. The test cases results for the functional testing of the application

\begin{tabular}{|c|c|c|c|c|c|}
\hline $\begin{array}{c}\text { Test } \\
\text { Case ID }\end{array}$ & Objective & Step & Expected Result & Actual Result & $\begin{array}{c}\text { Pass/ } \\
\text { Fail }\end{array}$ \\
\hline \multirow[t]{4}{*}{ TUC01 } & \multirow[t]{4}{*}{$\begin{array}{l}\text { Children can } \\
\text { choose the games } \\
\text { in the application }\end{array}$} & $\begin{array}{l}\text { Children open } \\
\text { LACLOD } \\
\text { application in the } \\
\text { mobile }\end{array}$ & $\begin{array}{l}\text { The application } \\
\text { display main } \\
\text { menu }\end{array}$ & $\begin{array}{l}\text { The application } \\
\text { display main } \\
\text { menu }\end{array}$ & Pass \\
\hline & & $\begin{array}{l}\text { Children click } \\
\text { button for game } 1\end{array}$ & $\begin{array}{l}\text { The application } \\
\text { display game } 1 \\
\text { play button }\end{array}$ & $\begin{array}{l}\text { The application } \\
\text { display game } 1 \\
\text { play button }\end{array}$ & Pass \\
\hline & & $\begin{array}{l}\text { Children play game } \\
1\end{array}$ & $\begin{array}{l}\text { The application } \\
\text { respond to the } \\
\text { user's interaction }\end{array}$ & $\begin{array}{l}\text { The application } \\
\text { respond to the } \\
\text { user's interaction }\end{array}$ & Pass \\
\hline & & $\begin{array}{l}\text { Children view } \\
\text { result for game } \\
1\end{array}$ & $\begin{array}{l}\text { The application } \\
\text { display user's } \\
\text { score }\end{array}$ & $\begin{array}{l}\text { The application } \\
\text { display user's } \\
\text { score }\end{array}$ & Pass \\
\hline \multirow[t]{2}{*}{ TUC04 } & \multirow{2}{*}{$\begin{array}{l}\text { Children can quit } \\
\text { the game by } \\
\text { clicking quit } \\
\text { button }\end{array}$} & $\begin{array}{l}\text { Children open } \\
\text { LACLOD App in } \\
\text { the mobile }\end{array}$ & $\begin{array}{l}\text { The application } \\
\text { display main } \\
\text { menu }\end{array}$ & $\begin{array}{l}\text { The application } \\
\text { display main } \\
\text { menu }\end{array}$ & Pass \\
\hline & & $\begin{array}{l}\text { Children click } \\
\text { button for quit } \\
\text { button }\end{array}$ & $\begin{array}{l}\text { The application } \\
\text { quit }\end{array}$ & $\begin{array}{l}\text { The application } \\
\text { quit }\end{array}$ & Pass \\
\hline \multirow[t]{3}{*}{ TUC05 } & \multirow{3}{*}{$\begin{array}{l}\text { Children can } \\
\text { view the } \\
\text { information of } \\
\text { the application }\end{array}$} & $\begin{array}{l}\text { Children open } \\
\text { LACLOD App in } \\
\text { the mobile }\end{array}$ & $\begin{array}{l}\text { The application } \\
\text { display main } \\
\text { menu }\end{array}$ & $\begin{array}{l}\text { The application } \\
\text { display main } \\
\text { menu }\end{array}$ & Pass \\
\hline & & $\begin{array}{l}\text { Children click } \\
\text { button for info } \\
\text { button }\end{array}$ & $\begin{array}{l}\text { The application } \\
\text { display app info }\end{array}$ & $\begin{array}{l}\text { The application } \\
\text { display app info }\end{array}$ & Pass \\
\hline & & $\begin{array}{l}\text { Children click back } \\
\text { button }\end{array}$ & $\begin{array}{l}\text { The application } \\
\text { back to main } \\
\text { menu }\end{array}$ & $\begin{array}{l}\text { The application } \\
\text { back to main } \\
\text { menu }\end{array}$ & Pass \\
\hline
\end{tabular}

Table 5. The test cases results for the functional testing of the Google Analytics (GA)

\begin{tabular}{|c|c|c|c|c|c|}
\hline $\begin{array}{c}\text { Test } \\
\text { Case ID }\end{array}$ & Objective & Step & Expected Result & Actual Result & $\begin{array}{c}\text { Pass/ } \\
\text { Fail }\end{array}$ \\
\hline \multirow[t]{5}{*}{ TUC07.1 } & \multirow{5}{*}{$\begin{array}{l}\text { To view the total } \\
\text { number of } \\
\text { numbers of users } \\
\text { in real time }\end{array}$} & $\begin{array}{l}\text { Teacher open } \\
\text { browser in computer }\end{array}$ & $\begin{array}{l}\text { Browser open in } \\
\text { the computer }\end{array}$ & $\begin{array}{l}\text { Browser open } \\
\text { in the computer }\end{array}$ & Pass \\
\hline & & $\begin{array}{l}\text { Teacher go to } \\
\text { GA website }\end{array}$ & GA page displayed & $\begin{array}{l}\text { GA page } \\
\text { displayed }\end{array}$ & Pass \\
\hline & & $\begin{array}{l}\text { Teacher login into } \\
\text { GA }\end{array}$ & $\begin{array}{l}\text { Teacher log into } \\
\text { GA with correct } \\
\text { email and } \\
\text { password }\end{array}$ & $\begin{array}{l}\text { Teacher log } \\
\text { into GA with } \\
\text { correct email } \\
\text { and password }\end{array}$ & Pass \\
\hline & & $\begin{array}{l}\text { Teacher go to } \\
\text { "REAL-TIME", } \\
\text { option }\end{array}$ & $\begin{array}{l}\text { GA display "real } \\
\text { time" interface }\end{array}$ & $\begin{array}{l}\text { GA display } \\
\text { "real time" } \\
\text { interface }\end{array}$ & Pass \\
\hline & & $\begin{array}{l}\text { Teacher view total } \\
\text { number users in real } \\
\text { time }\end{array}$ & $\begin{array}{l}\text { GA display total } \\
\text { number of users in } \\
\text { real time }\end{array}$ & $\begin{array}{l}\text { GA display } \\
\text { total number of } \\
\text { users in real } \\
\text { time }\end{array}$ & Pass \\
\hline
\end{tabular}


The International Journal of Multimedia \& Its Applications (IJMA) Vol.13, No. 1/2, April 2021

\begin{tabular}{|c|c|c|c|c|c|}
\hline $\begin{array}{c}\text { Test } \\
\text { Case ID }\end{array}$ & Objective & Step & Expected Result & Actual Result & $\begin{array}{c}\text { Pass/ } \\
\text { Fail }\end{array}$ \\
\hline \multirow[t]{3}{*}{ TUC07.2 } & \multirow[t]{3}{*}{$\begin{array}{l}\text { To view which } \\
\text { application's } \\
\text { screen viewed } \\
\text { the most }\end{array}$} & $\begin{array}{l}\text { Teacher still login } \\
\text { into GA }\end{array}$ & $\begin{array}{l}\text { Teacher still log } \\
\text { into GA with } \\
\text { correct e-mail and } \\
\text { password }\end{array}$ & $\begin{array}{l}\text { Teacher still } \\
\text { log into GA } \\
\text { with correct e- } \\
\text { mail and } \\
\text { password }\end{array}$ & Pass \\
\hline & & $\begin{array}{l}\text { Teacher go to } \\
\text { "REAL-TIME" } \\
\text { option then click } \\
\text { "Screens" }\end{array}$ & $\begin{array}{l}\text { GA display } \\
\text { "Screens" } \\
\text { interface }\end{array}$ & $\begin{array}{l}\text { GA display } \\
\text { "Screen" } \\
\text { interface }\end{array}$ & Pass \\
\hline & & $\begin{array}{l}\text { Teacher view } \\
\text { application's screen } \\
\text { viewed the most }\end{array}$ & $\begin{array}{l}\text { GA display the } \\
\text { most viewed screen }\end{array}$ & $\begin{array}{l}\text { GA display the } \\
\text { most viewed } \\
\text { screen }\end{array}$ & Pass \\
\hline \multirow[t]{3}{*}{ TUC07.3 } & \multirow[t]{3}{*}{$\begin{array}{l}\text { To view the } \\
\text { average time on } \\
\text { one screen per } \\
\text { one user }\end{array}$} & $\begin{array}{l}\text { Teacher still login } \\
\text { into GA }\end{array}$ & $\begin{array}{l}\text { Teacher still log } \\
\text { into GA with } \\
\text { correct e-mail and } \\
\text { password }\end{array}$ & $\begin{array}{l}\text { Teacher still } \\
\text { log into GA } \\
\text { with correct e- } \\
\text { mail and } \\
\text { password }\end{array}$ & Pass \\
\hline & & $\begin{array}{l}\text { Teacher go to } \\
\text { "BEHAVIOR" } \\
\text { option then click } \\
\text { "App Speed" }\end{array}$ & $\begin{array}{l}\text { GA display “App } \\
\text { Speed User } \\
\text { Timings" interface }\end{array}$ & $\begin{array}{l}\text { GA display } \\
\text { "App Speed } \\
\text { User Timings" } \\
\text { interface }\end{array}$ & Pass \\
\hline & & $\begin{array}{l}\text { Teacher view the } \\
\text { average time on one } \\
\text { screen per one user } \\
\text { result }\end{array}$ & $\begin{array}{l}\text { GA display } \\
\text { average time used } \\
\text { by one user }\end{array}$ & $\begin{array}{l}\text { GA display } \\
\text { average time } \\
\text { used by one } \\
\text { user }\end{array}$ & Pass \\
\hline \multirow[t]{4}{*}{ TUC07.4 } & \multirow[t]{4}{*}{$\begin{array}{l}\text { To view the } \\
\text { user's score }\end{array}$} & $\begin{array}{l}\text { Teacher still log on } \\
\text { GA }\end{array}$ & $\begin{array}{l}\text { Teacher still log } \\
\text { into GA with } \\
\text { correct e-mail and } \\
\text { password }\end{array}$ & $\begin{array}{l}\text { Teacher still } \\
\text { log into GA } \\
\text { with correct e- } \\
\text { mail and } \\
\text { password }\end{array}$ & Pass \\
\hline & & $\begin{array}{l}\text { Teacher go to } \\
\text { "BEHAVIOR" } \\
\text { option then click } \\
\text { "Top } \\
\text { Events" under } \\
\text { "Events" option }\end{array}$ & $\begin{array}{l}\text { GA displays "Top } \\
\text { Events" interface }\end{array}$ & $\begin{array}{l}\text { GA displays } \\
\text { "Top } \\
\text { Events" } \\
\text { interface }\end{array}$ & Pass \\
\hline & & $\begin{array}{l}\text { Teacher view user's } \\
\text { score }\end{array}$ & $\begin{array}{l}\text { GA displays score } \\
\text { per one user }\end{array}$ & $\begin{array}{l}\text { GA did not } \\
\text { display score } \\
\text { per one user }\end{array}$ & Fail \\
\hline & & $\begin{array}{l}\text { Teacher still log on } \\
\text { to GA }\end{array}$ & $\begin{array}{l}\text { Teacher still log } \\
\text { into GA with } \\
\text { correct e-mail and } \\
\text { password }\end{array}$ & $\begin{array}{l}\text { Teacher still } \\
\text { log into GA } \\
\text { with correct e- } \\
\text { mail and } \\
\text { password }\end{array}$ & Pass \\
\hline \multirow[t]{2}{*}{ TUC07.5 } & \multirow[t]{2}{*}{$\begin{array}{l}\text { To view which } \\
\text { button the user } \\
\text { interact the most }\end{array}$} & $\begin{array}{l}\text { Teacher still log on } \\
\text { Google Analytics }\end{array}$ & $\begin{array}{l}\text { Teacher still log } \\
\text { into GA with } \\
\text { correct e-mail and } \\
\text { password }\end{array}$ & $\begin{array}{l}\text { Teacher still } \\
\text { log into GA } \\
\text { with correct e- } \\
\text { mail and } \\
\text { password }\end{array}$ & Pass \\
\hline & & $\begin{array}{l}\text { Teacher go to } \\
\text { "BEHAVIOR" } \\
\text { option then click } \\
\text { "Top } \\
\text { Events" under }\end{array}$ & $\begin{array}{l}\text { GA display "Top } \\
\text { Events" interface }\end{array}$ & $\begin{array}{l}\text { GA display } \\
\text { "Top } \\
\text { Events" } \\
\text { interface }\end{array}$ & Pass \\
\hline
\end{tabular}


The International Journal of Multimedia \& Its Applications (IJMA) Vol.13, No. 1/2, April 2021

\begin{tabular}{|c|c|c|c|c|c|}
\hline \multirow[t]{3}{*}{$\begin{array}{c}\text { Test } \\
\text { Case ID }\end{array}$} & Objective & Step & Expected Result & Actual Result & $\begin{array}{c}\text { Pass/ } \\
\text { Fail }\end{array}$ \\
\hline & & "Events" option & & & \\
\hline & & $\begin{array}{l}\text { Teacher view which } \\
\text { button that the one } \\
\text { user interact the } \\
\text { most }\end{array}$ & $\begin{array}{l}\text { GA display the top } \\
\text { button clicked by } \\
\text { the users }\end{array}$ & $\begin{array}{l}\text { GA display the } \\
\text { top button } \\
\text { clicked by the } \\
\text { users }\end{array}$ & Fail \\
\hline
\end{tabular}

Table 6. The checklist used for the evaluation during observation of the children

\begin{tabular}{ll} 
No. & Details \\
\hline S1 & $\begin{array}{l}\text { Does the students find it is hard to navigate the application? } \\
\text { To determine the user interfaces of the application whether it is a user-friendly mobile application. }\end{array}$ \\
\hline S2 & $\begin{array}{l}\text { Does the students able to understand the audio in the application? } \\
\text { To determine if the content of the application is being understandable by the children as they } \\
\text { cannot read yet. }\end{array}$ \\
S3 & $\begin{array}{l}\text { Does the students know how to use the buttons in the application? } \\
\text { To determine the graphic element of the application is being understandable by the children as the } \\
\text { buttons do not have text to explain each function of it }\end{array}$ \\
S4 & $\begin{array}{l}\text { Does the students know how to play the game? } \\
\text { To determine the learnability of the application. }\end{array}$ \\
\hline S5 & $\begin{array}{l}\text { Does the students look happy when they play the application? } \\
\text { To determine the satisfaction factor for the application when the children are played with it. }\end{array}$
\end{tabular}

Table 7. The questions asked to the teachers to evaluate the ease of use of the application

\begin{tabular}{|c|c|}
\hline No. & Details \\
\hline \multirow[t]{2}{*}{ U1 } & Is it hard to navigate the application? \\
\hline & $\begin{array}{l}\text { To determine the user interfaces of the application whether it is a user-friendly mobile } \\
\text { application. }\end{array}$ \\
\hline \multirow[t]{2}{*}{$\mathbf{U 2}$} & Is the audio in the application is clear and understandable? \\
\hline & $\begin{array}{l}\text { To find out if the content of the application is being understandable by the children as they } \\
\text { cannot read yet }\end{array}$ \\
\hline \multirow[t]{2}{*}{ U3 } & Is the objectives for each game is suitable for learning? \\
\hline & To analyse whether the games play is suitable with the objectives. \\
\hline \multirow[t]{2}{*}{ U4 } & Is the graphics design in the application is suitable for the children? \\
\hline & To determine if the content of the images in the application is suitable \\
\hline \multirow[t]{2}{*}{ U5 } & Do you want to use this application for your students in the class? \\
\hline & To determine whether the application give impact to the children from the teachers' perspective. \\
\hline
\end{tabular}

Table 8. The questions asked to the teachers to evaluate the ease of use of the Google Analytics (GA)

\begin{tabular}{ll}
\hline No. & Details \\
\hline V1 & $\begin{array}{l}\text { Have you ever use Google Analytics before? } \\
\text { To determine the first time user. }\end{array}$ \\
\hline V2 & $\begin{array}{l}\text { Is Google Analytics is easy for you to use? } \\
\text { To find out if the content of the application is being understandable by the children as they cannot } \\
\text { read yet }\end{array}$ \\
\hline V3 & $\begin{array}{l}\text { Do you take time to explore on how to use Google Analytics? } \\
\text { To determine the ease of learnability for Google Analytics. }\end{array}$ \\
\hline V4 & $\begin{array}{l}\text { Do you understand what Google Analytics is used for? } \\
\text { To get to know on the teachers' perspective on Google Analytics }\end{array}$ \\
\hline V5 & $\begin{array}{l}\text { Do you want to use Google Analytics to track your students' performance in the future? } \\
\text { To determine whether the Google Analytics give benefits to the teachers from their perspective. }\end{array}$ \\
\hline
\end{tabular}

